In summary, patients with the chronic fatigue syndrome show impaired capacity for exercise despite an increased perception of their exertion. We found no evidence for a deficient cardiovascular response or peripheral muscle function other than that which would be expected as a result of deconditioning. Other mechanisms, however, such as atrophy of muscle fibre or depletion of muscle enzymes may result in similar findings and merit further investigation.

1 Behan PO, Behan WHM, Bell EJ. The post-viral fatigue syndrome-an analysis of findings in 50 cases. F Infect 1985;10:211-22.

2 Bell EJ, McCartney RA, Riding MH. Coxsackie B viruses and mylagic Bell EJ, McCartney RA, Riding MH. Coxsackie
encephalomyelitis. I R Soc Med 1988;81:329-31.

3 Holmes GP, Kaplan JE, Gantz NM, et al. Chronic fatigue syndrome; a working case definition. Ann Intern Med 1988;108:387-9.

+ Manning AP, Thompson WG, Heaton KW, Morris AF. Towards positive diagnosis of the irritable bowel. Br Med F 1978; ii:653-4.

5 Bruce RA. Exercise testing of patients with coronary artery disease. Annals of Clinical Research 1971;3:323-32.

6 Borg GAV. Psychophysical basis of perceived exertion. Med Sci Sports Exerc 1982;14:377-81.

7 Elborn JS, Stanford CF, Nicholls DP. Reproducibility of cardiopulmonary parameters during exercise in patients with chronic cardiac failure. The need for a preliminary test. European fournal of Cardiology 1990;11:75-81.

8 Clode M, Campbell EJM. The relationship between gas exchange and changes in blood lactate concentrations during exercise. Clin Sci 1969;37:263-72.
9 Jones NL. Clinical exercise testing. 3rd ed. Philadelphia: W B Saunders, 988:213-30.

10 Saltin B, Blomqvist B, Mitchell JH, Johnston RL, Wildenthal K, Chapman CB. Response to submaximal and maximal exercise after bedrest and training. Circulation 1968;38 (suppl 7):1-78.

11 Holloszy JO, Booth FW. Biochemical adaptations to endurance exercise in muscle. Annu Rev Physiol 1976;38:263-91.

12 Montague TJ, Marrie TJ, Klassen GA, Bewick DJ, Horacek BM. Cardiac function at rest and with exercise in the chronic fatigue syndrome. Chest 1989;95:779-84.

13 Arnold DL, Radda GK, Bore PJ, Styles P, Taylor DJ. Excessive intracellula acidosis of skeletal muscle on exercise in a patient with a post-vira exhaustion/fatigue syndrome. Lancet 1984; 1 : 1367-9.

14 Archard LC, Bowles NE, Behan PO, Bell EJ, Doyle D. Post viral fatigue syndrome: persistence of enteroviral RNA in skeletal muscle and elevated creatine kinase. $\mathcal{F} R$ Soc Med 1988;81:326-9.

15 Byrne E, Trounce I. Chronic fatigue and myalgic syndrome: mitochondrial and glycolytic studies in skeletal muscle. I Neurol Neurosurg Psychiatry 1987;50:743-6.

16 Beaudet AL. The glycogen storage of diseases. In: Braunwald E, Isselbache KJ, Petersdorf RG, Wilson JD, Martin JB, Fauci AS, eds. Harrison's principles of internal medicine. 11th ed. New York: McGraw-Hill, 1987:1648.

17 McEvedy CP, Beard AW. Royal Free epidemic of 1955: a reconsideration. BrMed F 1970;i:7-11.

18 Woods JJ, Furbush F, Bigland-Ritchie B. Evidence for a fatigue-induced reflex inhibition of motorneuron firing rates. F Neurophysiol 1987;58:125-37.

19 Stokes MJ, Cooper RG, Edwards RHT. Normal muscle strength and fatigability in patients with effort syndromes. Br Med f 1988;297:1014-7.

(Accepted 25 fuly 1990)

\section{Department of}

Haematology, Royal

Infirmary of Edinburgh,

Edinburgh EH3 9YW

R J G Cuthbert, MRCP,

lecturer

C A Ludlam, FRCPATH, consultant

J Tucker, MRCPATH, senior registrar

\section{MRC Human Genetics} Unit, Western General Hospital, Edinburgh EH4 2XU

C M Steel, FRCP, assistant

director

D Beatson, FIMLs, medical

laboratory scientific officer

Department of

Bacteriology, University of

Edinburgh, Edinburgh

S Rebus, BSC, medical

laboratory scientific officer

J F Peutherer, FRCPATH,

senior lecturer

Correspondence to: $\mathrm{Dr}$

R J G Cuthbert, Department

of Haematology, City

Hospital, Nottingham NG5

1PB.

BrMed f 1990;301:956-61

\title{
Five year prospective study of HIV infection in the Edinburgh haemophiliac cohort
}

\author{
R J G Cuthbert, C A Ludlam, J Tucker, C M Steel, D Beatson, S Rebus, J F Peutherer
}

\section{Abstract}

Objective-To identify measures of immune state that reflect the course of HIV related disease in order to predict deterioration of symptoms and assess response to treatment.

Design-Five year longitudinal clinical and laboratory study.

Setting-Regional haemophilia centre, university virology laboratory, and Medical Research Council laboratory.

Patients - 32 Patients with haemophilia A exposed to a single batch of HIV contaminated factor VIII concentrate from the Scottish National Blood Transfusion Service in 1984 who were followed up regularly in Edinburgh (31) or abroad (one).

Main outcome measures-Counts of circulating $\mathbf{T}$ cell subsets (CD4 and CD8); plasma $\beta_{2}$ microglobulin, neopterin, and $\operatorname{IgA}$ concentrations; and delayed type hypersensitivity to multiple skin test antigens.

Results-18 Patients who seroconverted after exposure had received significantly more contaminated factor VIII than the 14 who did not (mean 43 (range 9-109) $v 15(3-30)$ phials, $\mathbf{p}<0.01)$. The two groups were not distinguishable by other criteria before exposure. The group that seroconverted subsequently showed a progressive fall in mean circulating CD4 lymphocytes and an increase in plasma $\beta_{2}$ microglobulin and neopterin concentrations. From 1987 patients in this group also showed an increase in mean circulating CD8 lymphocytes and in plasma IgA concentration, neither of which was seen in patients who did not seroconvert. Patients with HIV antibody who developed Centers for Disease Control category IV symptoms within five years after infection showed more extreme changes in all measures, except CD8 lymphocyte count, than those whose symptoms remained in categories II and III. Skin test reactivity declined to barely detectable levels in all patients positive for HIV antibody.

Conclusions-Serial estimates of circulating CD4 lymphocytes and of plasma $\beta_{2}$ microglobulin concentration are the most reliable measures of disease progression; of these, $\beta_{2}$ microglobulin concentration seems to be the better predictor of impending serious symptoms. High IgA concentrations reflect rather than predict disease state. Individual variation in most measures is such that a wide range of measurements should be used in assessing the effects of trial treatment in HIV infected patients without symptoms.

\section{Introduction}

The early identification of individual patients who have a poor prognosis for HIV disease is an important objective. It may, for example, permit initiation of antiviral treatment at a stage before serious clinical deterioration and has therefore been a goal of many cohort studies of HIV infection. ${ }^{1}$ Among the prognostic variables identified in some or all of these reports have been age at seroconversion ${ }^{23}$; declining CD4 cell counts ${ }^{2-8}$ and rising CD8 cell counts ${ }^{4}$; rising plasma $\beta_{2}$ microglobulin, ${ }^{58}$ neopterin, ${ }^{89}$ and IgA $^{5.8}$ concentrations; and altered delayed type hypersensitivity responses. ${ }^{111}$ Though there is universal agreement on the value of serial CD4 cell counts to track the course of infection, there is no consensus on which additional variable or combination of variables might be useful for early detection of those patients at greatest risk of rapid progression to symptomatic disease. ${ }^{1}$ One difficulty common to virtually all published studies is that the times of onset and the sources of infection are very heterogeneous. We previously described a unique group of haemophiliac patients infected with HIV from a single batch of factor VIII concentrate used between March and May 1984. ${ }^{12}$ This led inadvertently to the establishment of a cohort of individual patients with a common source of infection, whose times of HIV seroconversion were clearly recorded. Since that report three further seroconversions have occurred among members of the cohort. In this study we reanalyse the data on seroconversion and describe 
clinical and laboratory findings throughout a five year follow up. We assessed several measures of immune function as indices of disease state in this cohort of haemophiliac patients.

\section{Patients and methods}

The study group comprised 32 patients with haemophilia who received factor VIII concentrate from a single HIV contaminated batch from the Scottish National Blood Transfusion Service. ${ }^{12}$ All but one of the patients were seen for regular follow up in Edinburgh. The exception was a man who has lived overseas since 1985. Information on the clinical course of his disease and laboratory findings were made available by his current doctor.

Full blood counts and differential leucocyte counts were measured with a Coulter S Plus counter, and the differential counts were confirmed by examination of peripheral blood films stained with Romanowsky's stain. Total lymphocyte counts were calculated by computing the absolute values from the differential and total white cell counts. Peripheral blood lymphocytes were separated from heparinised whole blood by centrifugation over Ficoll-Hypaque (specific gravity 1.078 ) and washed twice in phosphate buffered saline. The CD4 and CD8 lymphocyte subsets were estimated initially by indirect immunofluorescence, with mouse monoclonal antibodies (Dako) in the first layer and fluorescein isothiocyanate conjugated $F(a b)$ fractions of sheep antimouse immunoglobulin (Sigma) in the second. Latterly, directly conjugated CD4 and CD8 antibodies were used (Becton-Dickinson IMK or similar test kits). The stained cells were then resuspended in phosphate buffered saline with $1 \%$ formaldehyde and scored on a Becton-Dickinson FACS IV or FACScan cytopherometer.

Plasma samples collected at regular clinical follow up appointments were stored at $-20^{\circ} \mathrm{C}$ and subsequently used for immunological and virological studies. Plasma $\beta_{2}$ microglobulin and neopterin concentrations were estimated by competitive radioimmunoassay techniques (Pharmacia and Henning, respectively). Total plasma $\operatorname{IgA}$ concentration was measured by single radial diffusion on commercially prepared Mancini plates (Behring).

Intradermal delayed type hypersensitivity response to recall antigens (a measure of cell mediated immunity) was assessed by a multitest applicator system (Merieux), which includes a negative control. The antigens were tetanus toxoid, diphtheria toxoid, streptococcus antigen, Trichophyton mentagrophytes antigen, Candida albicans antigen, old tuberculin, and Proteus mirabilis antigen. A positive response was indicated by a mean diameter of palpable skin induration $>2 \mathrm{~mm}$ at 48 hours.

HIV antibodies were detected by competitive enzyme linked immunosorbent assay (ELISA, Wellcome) and confirmed by western blotting. HIV p24 antigen was detected by antigen capture ELISA

TABLE I-Variables before exposure to HIV during treatment with batch A factor VIII in haemophiliac patients who did or did not subsequently seroconvert. Values are means (ranges)

\begin{tabular}{|c|c|c|c|}
\hline & $\begin{array}{l}\text { Patients who } \\
\text { seroconverted }(n=18)\end{array}$ & $\begin{array}{l}\text { Patients who did not } \\
\text { seroconvert }(n=14)\end{array}$ & \\
\hline $\begin{array}{l}\text { Age (years) } \\
\text { No of phials of batch A }\end{array}$ & $31(14 \cdot 0-42 \cdot 5)$ & $24(16 \cdot 0-56 \cdot 2)$ & NS \\
\hline Annual amount of factor VIII $\times 10^{3}$ & $43(9-109)$ & $15(3-30)$ & $p<0.01$ \\
\hline $\begin{array}{l}\text { (unity) in } 1983 \\
\text { CD4 lymphocyte count }\left(\times 10^{9} / 1\right)\end{array}$ & $\begin{array}{c}46 \cdot 3(0 \cdot 0-98 \cdot 8) \\
0 \cdot 69(0 \cdot 32-1 \cdot 45) \\
(n=17)\end{array}$ & $\begin{array}{c}36 \cdot 0(0 \cdot 0-133 \cdot 7) \\
0 \cdot 82(0 \cdot 40-1 \cdot 28) \\
(n=6)\end{array}$ & $\begin{array}{l}\text { NS } \\
\text { NS }\end{array}$ \\
\hline Plasma neopterin (nmol/l) & $\begin{array}{c}8 \cdot 5(6 \cdot 8-11 \cdot 0) \\
(n=18)\end{array}$ & $\begin{array}{c}7 \cdot 7(4 \cdot 8-9 \cdot 6) \\
(n=11)\end{array}$ & NS \\
\hline Plasma $\beta_{2}$ microglobulin $(\mathrm{mg} / \mathrm{l})$ & $\begin{array}{c}2 \cdot 06(1 \cdot 6-2 \cdot 9) \\
(n=18)\end{array}$ & $\begin{array}{c}1 \cdot 9(1 \cdot 5-2 \cdot 6) \\
(n=11)\end{array}$ & NS \\
\hline Plasma IgA (g/l) & $\begin{array}{c}2 \cdot 88(1 \cdot 1-4 \cdot 75) \\
(n=18)\end{array}$ & $\begin{array}{c}3 \cdot 22(1 \cdot 69-5 \cdot 41) \\
(n=11)\end{array}$ & NS \\
\hline
\end{tabular}

(Dupont). Full details of these studies and of virus culture have been reported. ${ }^{1{ }^{14}}$ Non-parametric statistical analyses were conducted. The Mann-Whitney U test was used to assess the significance of differences in results between groups. Two tailed probabilities are given.

\section{Results}

\section{SEROCONVERSION}

Our original study reported the development of HIV antibodies in 16 haemophiliac patients in Edinburgh between April and October 1984. ${ }^{12}$ During follow up three further seroconversions were observed between October and December 1984..$^{13}$ Re-examination of transfusion records confirmed that all but one of the original cohort had received a common batch (batch A) of factor VIII concentrate from the Scottish National Blood Transfusion Service between March and May 1984. One patient, originally reported as receiving the implicated batch, was found, however, not to have acquired his infection from this material. No further HIV seroconversions have occurred in haemophiliac patients in Edinburgh since the introduction of heat treated factor VIII in December 1984. No individual patient in this study is known to have other risk factors for acquiring HIV infection.

Re-examination of the transfusion records confirmed that 13 other patients with haemophilia $A$ and one with von Willebrand's disease had received factor VIII from batch $A .{ }^{12}$ All 14 subsequently remained negative for HIV antibody after five years' follow up. Eight patients with haemophilia B and two with haemophilia A (with inhibitors to factor VIII) who received factor IX concentrate (batch $\mathrm{C})^{12}$ manufactured from the same source plasma as batch A also remained negative for HIV antibody after five years' follow up.

The group of 18 patients who seroconverted after exposure had received significantly higher amounts of batch A compared with the 14 who remained negative for HIV antibody (mean 43 (range 9-109) $v$ mean 15 (3-30) phials, $\mathrm{p}<0.01)$. No significant differences in severity of haemophilia; age; annual dosage of factor VIII; or T cell subset counts, $\beta_{2}$ microglobulin, or IgA concentration before exposure were observed between the group that did seroconvert and the group that did not (table I). The same was true for plasma neopterin concentration, in contrast to the suggestion that raised neopterin concentration, which reflects macrophage activation, may be associated with an increased risk of seroconversion after exposure to HIV in nonhaemophiliac risk groups. ${ }^{9}$ Apart from episodic haemarthroses, all 32 patients were clinically well before transfusion of batch $\mathrm{A}$. All patients had evidence of chronic persistent hepatitis, manifested by fluctuating increased activities of liver transaminases. No patient, however, had symptomatic liver disease before exposure to batch $\mathrm{A}$.

Seroconversion times after exposure ranged from one to six months and have been reported in detail previously. ${ }^{12}{ }^{13}$ The latest seroconverters had received the smallest amounts of batch A (nine, 10, and 20 phials), which may be relevant, but for the group as a whole there were no significant differences in dosage of batch A, age, severity of liver disease, or immunological variables before exposure between early $(<80$ days) and late ( $>80$ days) seroconverters. Thus factors that may influence the early immunological response to HIV could not be identified from this study.

\section{CLINICAL FOLLOW UP}

None of the 14 patients negative for HIV antibody had any clinical manifestations of HIV infection five years after exposure to batch A. Table II outlines the clinical state, year by year, for the group of 18 
TABLE II-Clinical state of haemophiliac patients who seroconverted, 1984-9

\begin{tabular}{|c|c|c|c|c|c|c|c|c|c|}
\hline \multirow[b]{2}{*}{ Case No } & \multirow{2}{*}{$\begin{array}{l}\text { HLA-A1 } \\
\text { B8 DR3 }\end{array}$} & \multirow[b]{2}{*}{ Year of birth } & \multirow{2}{*}{$\begin{array}{l}\text { No of phials of } \\
\text { contaminated factor } \\
\text { VIII received }\end{array}$} & \multicolumn{6}{|c|}{ Aids state (CDC category's) } \\
\hline & & & & 1984 & 1985 & 1986 & 1987 & 1988 & 1989 \\
\hline 1 & - & 1965 & 23 & II & II & II & II & II & II \\
\hline 2 & - & 1959 & 9 & II & III & III & $\mathrm{IV}_{\mathrm{c}_{2}}$ & $\mathrm{IV}_{\mathrm{c}_{2}}$ & $\mathrm{IV}_{2}$ \\
\hline 3 & - & 1962 & 81 & II & II & II & II & II & $\mathrm{IVc}_{1}$ \\
\hline 4 & - & 1946 & 20 & II & II & II & II & II & II \\
\hline 5 & - & 1963 & 20 & II & II & II & II & II & II \\
\hline 6 & - & 1947 & 10 & II & II & $\mathrm{IV}_{\mathrm{c}_{2}}$ & $\mathrm{IV}_{\mathrm{c}_{2}}$ & $\mathrm{IV}_{\mathrm{c}_{2}}$ & $\mathrm{IVc}_{2}$ \\
\hline 7 & - & 1950 & 60 & II & II & II & II & II & II \\
\hline 8 & - & 1944 & 20 & III & III & III & III & III & III \\
\hline 9 & - & 1946 & 60 & II & II & II & II & II & II \\
\hline 10 & - & 1941 & 10 & II & II & II & II & II & II \\
\hline 11 & + & 1948 & 81 & II & II & II & $\mathrm{IV}_{\mathrm{c}_{2}}$ & IVd & $\mathrm{IVd}^{\star}$ \\
\hline 12 & + & 1962 & 43 & II & III & IVa & IVa & IVa & IVa \\
\hline 13 & + & 1954 & 51 & II & II & IVet & IVe & IVe & IVe \\
\hline 14 & + & 1941 & 109 & II & II & IVa & IVa & IVa & IVa \\
\hline 15 & + & 1969 & 30 & III & III & III & III & III & III \\
\hline 16 & + & 1942 & 50 & II & II & IVa & IVa & IVa & $\mathrm{IV}_{c_{1}, \mathrm{e}}$ \\
\hline 17 & + & 1970 & 54 & I & IVa & $\mathrm{IVb}, \mathrm{c}_{1}$ & $\mathrm{IVd}^{\star}$ & & \\
\hline 18 & + & 1945 & 20 & II & II & II & $\mathrm{IVa}^{\star}$ & & \\
\hline
\end{tabular}

$\star$ Died.

†Thrombocytopenia.

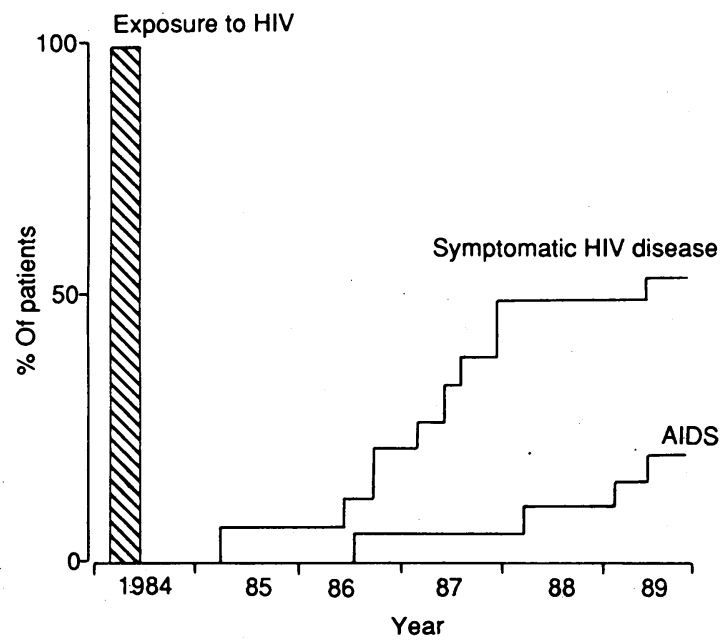

FIG 1-Five year cumulative incidence of symptomatic HIV disease (Centers for Disease Control stage IV) and of AIDS by life table analysis in Edinburgh haemophiliac cohort

- Patients negative for HIV antibody $(n=14)$

- Patients positive for HIV antibody ( $n=18)$

- Patients positive for HIV antibody with CDC IV disease five years after exposure $(n=10)$ - Patients positive for HIV antibody with CDC category I or II disease $(n=8)$

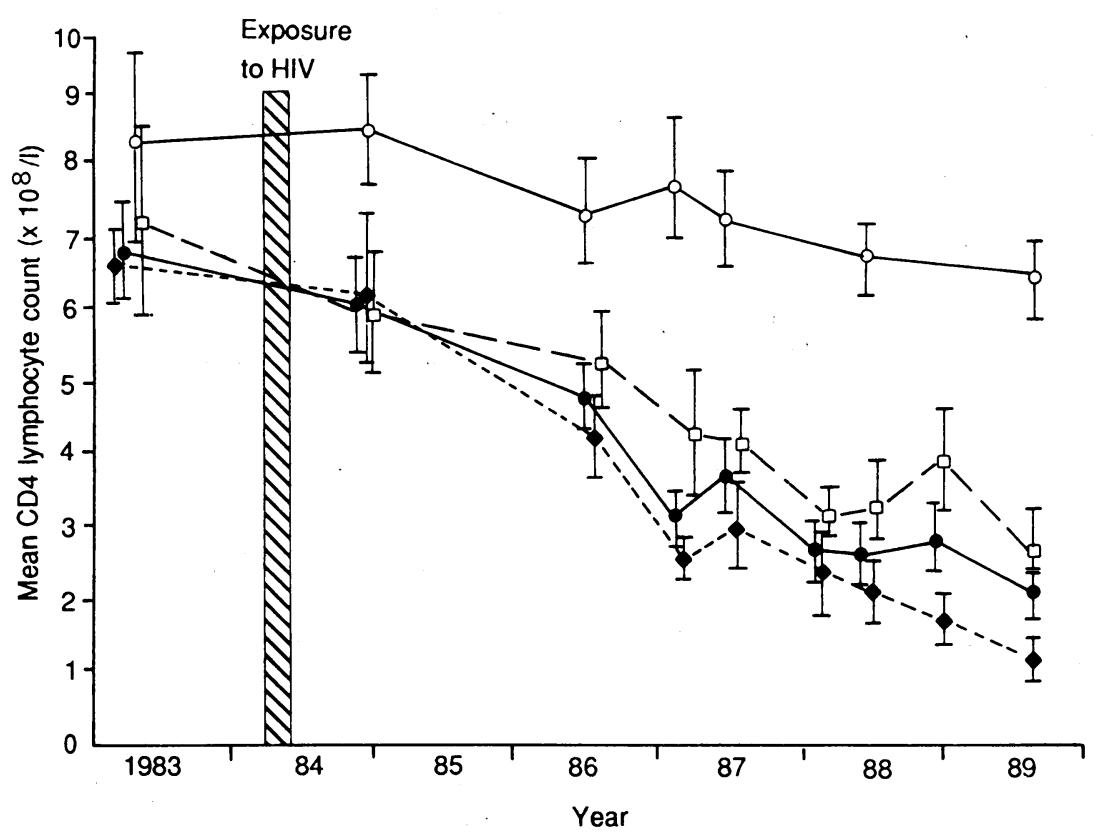

FIG 2-Serial mean counts of circulating CD4 lymphocytes in members of Edinburgh haemophiliac cohort who did and did not seroconvert after exposure to contaminated factor VIII. Bars are 2SE recipients of batch A who seroconverted, and figure 1 shows that the cumulative incidence of serious HIV disease (Centers for Disease Control (CDC) category IV) was $55 \cdot 5 \%(10 / 18)$ at five years. For all the analyses in this report the group positive for HIV antibody was subdivided into the 10 patients "with symptoms" - that is, those who developed CDC category IV disease at any point up to mid-1989 (five years after exposure to infection)-and the eight patients "without symptoms"-that is, who remained in CDC category II or III..$^{15}$ Age, annual dosage of factor VIII, incidence of bleeding episodes, and severity of liver disease (as assessed by plasma alanine aminotransferase activities) were not significantly different between the patients with and without symptoms. Although the patients with symptoms had received, on average, more phials of the contaminated batch $\mathrm{A}(51 \mathrm{v}$ 30 ), the difference was not significant, and there was no discernible relation between the number of phials received and the time elapsing before symptoms appeared; nor did the time taken to seroconvert seem to affect the subsequent rate of disease progression.

Four patients positive for HIV antibody (three with symptoms and one without) received zidovudine in various doses, one starting treatment in 1987 and the others in 1988.

\section{IMMUNOLOGICAL VARIABLES}

CD4 lymphocyte counts-Figure 2 shows that serial counts of circulating CD4 lymphocytes clearly distinguished patients with and without HIV antibody within the cohort; among the patients with HIV antibody mean CD4 counts fell more rapidly in those with symptoms. There were, however, individual exceptions to this general pattern. One patient with HIV antibody had had a low CD4 count $(<0.35 \times$ $10^{9} / 1$ ) since 1983 , before exposure to the virus. It remained about the same for six years and he had no symptoms. Another patient had a CD4 count of only $0 \cdot 14 \times 10^{9} / 1$ in a sample taken before infection and it remained between $0 \cdot 1$ and $0 \cdot 15 \times 10^{9} / 1$ until mid-1988. Despite zidovudine treatment it subsequently fell below $0.1 \times 10^{9} / 1$, and the patient had CDC category IVa symptoms from late' 1986 . For predicting clinical deterioration single estimations of numbers of circulating CD4 cells are of very limited value, though a downward trend with time is more meaningful. We found that a decline to $0.2 \times 10^{9} / 1$ did not necessarily precede symptoms. Indeed, with the exception of the patient whose count before infection was already low, all members of our subgroup with symptoms had developed CDC category IV disease before their CD4 counts fell to that value. On the other hand, CD4 counts in three of the subgroup without symptoms subsequently reached that value, two within the past few months but the third more than a year ago.

CD8 lymphocyte counts - In contrast to some other studies, ${ }^{45}$ we had not initially observed any significant change in the numbers of circulating CD8 lymphocytes in this cohort. It is now evident that an increase in the mean count of $\mathrm{CD} 8$ cells took place in the group positive for HIV antibody but not until three years after seroconversion (fig 3). At five years' follow up a significant difference between the patients with and without HIV antibody was apparent for the first time. The transient rise in the curve for the group negative for antibody over the latter part of 1987 remains unexplained. An assay bias may have occurred in estimating total lymphocyte counts at this time. CD8 counts were not consistently different between subgroups of patients positive for HIV antibody and with or without symptoms.

$\beta_{2}$ Microglobulin - The pattern of change in mean plasma $\beta_{2}$ microglobulin concentration (fig 4a) was virtually the obverse of that for CD4 cells. The group 


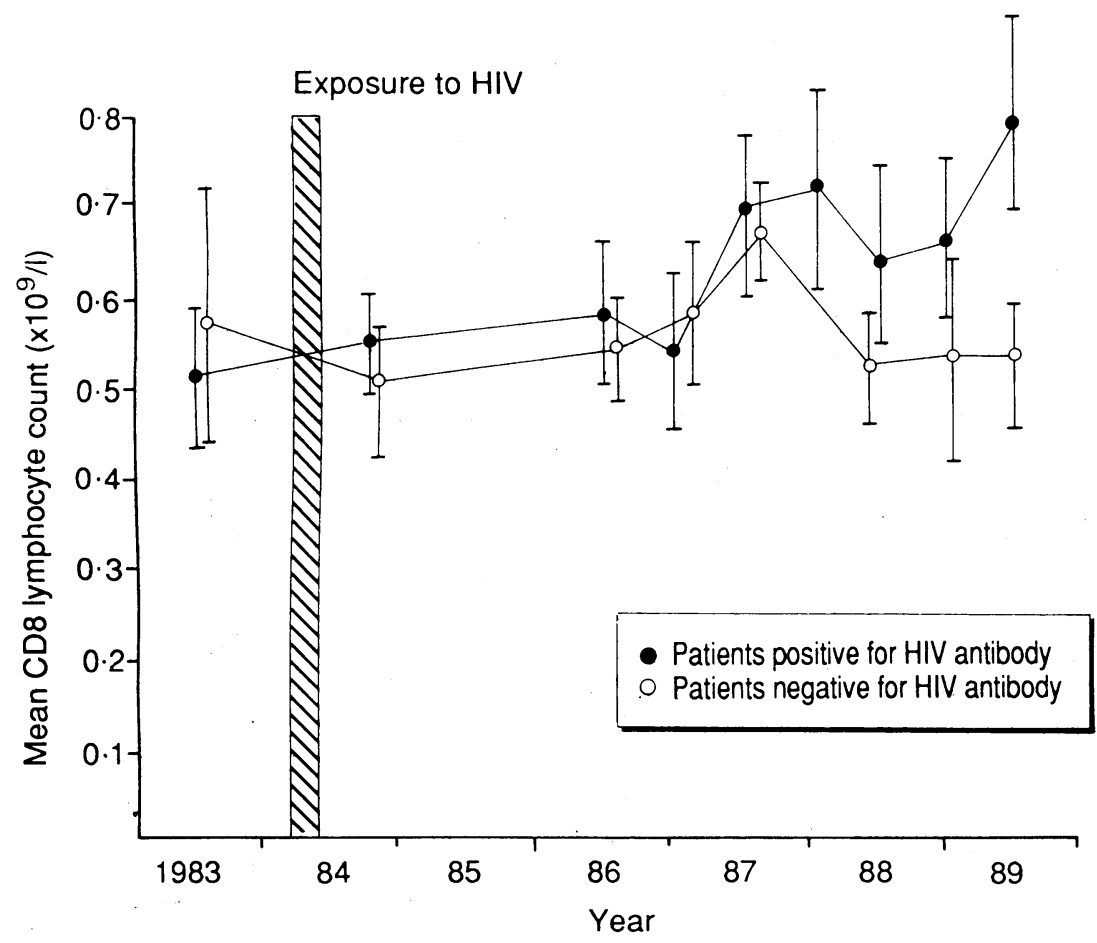

FIG 3-Serial mean counts of circulating CD8 lymphocytes in members of Edinburgh haemophiliac cohort with and without HIV antibody. Bars are $2 S E$

positive for HIV antibody diverged progressively from that negative for the antibody, and at all time points after infection the mean plasma $\beta_{2}$ microglobulin concentration was higher in the subgroup positive for HIV antibody with symptoms than in that without symptoms. Variations in concentration between individual members of the subgroup and between successive estimations for the same patient were not great, which makes $\beta_{2}$ microglobulin concentration a particularly useful marker of disease progression. In this cohort a cut off value of $3 \mathrm{mg} / \mathrm{l}$ allowed a clear distinction between the groups. In only two of the patients negative for HIV antibody had the $\beta_{2}$ microglobulin concentration reached this value (a single reading, in each case, of 3.2 and $3.3 \mathrm{mg} / \mathrm{l}$ in 1984 and 1987 respectively) whereas in all nine patients positive for HIV antibody and with symptoms from whom we repeated measurements it had done so. In eight of that group $\beta_{2}$ microglobulin concentrations were $\geqslant 3 \mathrm{mg} / \mathrm{l}$ by mid-1986 and in five of them that concentration was attained at least one year before symptoms developed. In all patients the increase was persistent and usually progressive. Among the patients positive for HIV antibody without symptoms, only one had a prolonged increase in $\beta_{2}$ microglobulin concentration $(>3 \mathrm{mg} / \mathrm{l}$ since the latter part of 1984), but two more showed values consistently above this concentration from mid1987 and mid-1988 respectively.

Mean plasma neopterin concentrations, as those of $\beta_{2}$ microglobulin, were higher in the group positive for HIV antibody and particularly so in the patients with symptoms (fig $4 \mathrm{~b}$ ). These measurements, however, were characterised by wide fluctuations among patients and between consecutive estimations for the same patient. A cut off value of $12 \mathrm{nmol} / \mathrm{l}$ proved useful in this cohort. In only one of the group negative for HIV antibody did the concentration reach this value (a single reading of $13 \mathrm{nmol} / \mathrm{l}$ in 1986) whereas it did so in all nine in the subgroup positive for HIV antibody with symptoms for whom we had regular readings and three of the eight patients in the subgroup positive for HIV antibody without symptoms. In one of the three the increase was first noted in 1984 and subsequently became much more pronounced, and in the other two values $>12 \mathrm{nmol} / 1$ were recorded only since 1988 . The
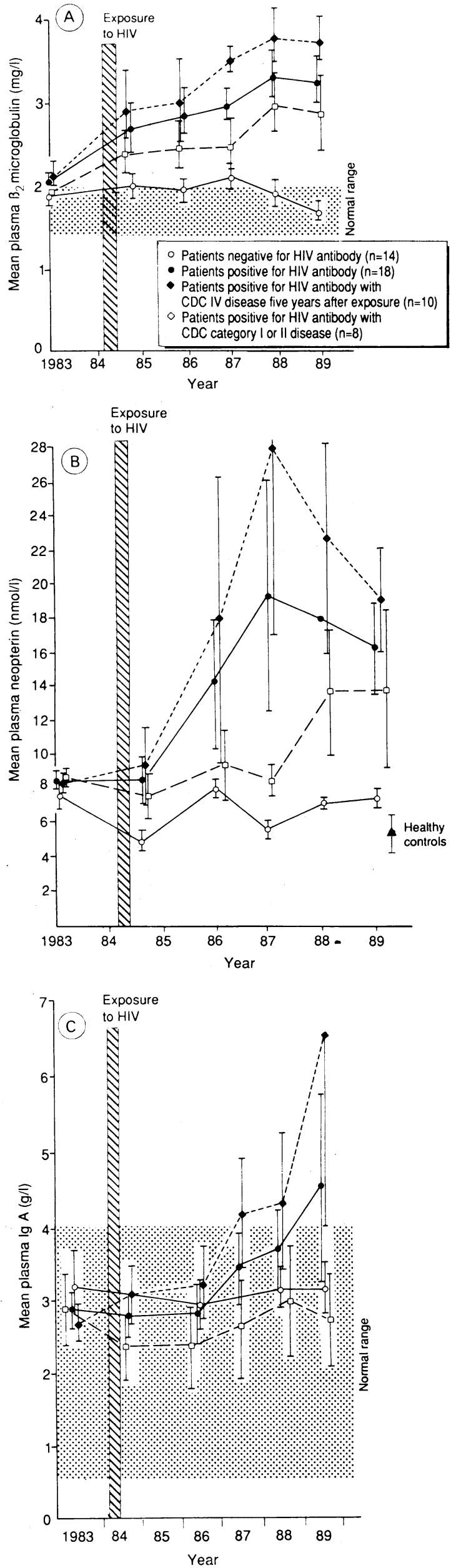

FIG 4-Immunological variables in members of Edinburgh haemophiliac cohort: (a) serial mean plasma $\beta_{2}$ microglobulin concentration; (b) neopterin concentration; (c) IgA concentration. Bars are $2 S E$ 
predictive value of the measurement in the asymptomatic stage is doubtful from this study as only two patients in our group with symptoms had an increased plasma neopterin concentration a year or more before onset of CDC category IV disease.

IgA - The mean plasma IgA concentration started to increase three years after seroconversion (fig $4 \mathrm{c}$ ), and this shift was almost entirely attributable to the subgroup with symptoms. Analysis of patterns in individual patients, however, showed that the trend was not consistent. Three of the patients with symptoms showed no convincing rise in IgA concentration, and in all patients in whom the rise was unequivocal (reaching $\geqslant 5 \mathrm{~g} / \mathrm{l}$ ) this happened only after symptomatic disease was recognised. Two of the patients with HIV antibody without symptoms had IgA concentrations $>5 \mathrm{~g} / \mathrm{l}$. In one patient this progressed, but in the other, whose IgA concentration before infection was $4.75 \mathrm{~g} / \mathrm{l}$, only the latest $(1989)$ value was above that $(5 \cdot 4 \mathrm{~g} / 1)$. Two members of the subgroup without HIV antibody had repeated (but not rising) values marginally above $5 \mathrm{~g} / \mathrm{l}$.

Cell mediated immunity-Skin test delayed hypersensitivity responses on initial examination in 1984-5 were depressed in all members of the cohort compared with those in healthy age matched subjects (fig 5). Repeat testing in 1987-8 (in all patients except one in the group positive for HIV antibody) showed a further decline in the subgroup with HIV antibody, which is now distinguishable from the subgroup without antibody. The overall response was so low that no correlation was evident with clinical state in individual patients positive for HIV antibody.

\section{Discussion}

Although immunological abnormalities in patients with haemophilia A are well recognised without HIV infection, ${ }^{16} 17$ information from this uniquely homogeneous cohort is of special value because its members were assessed immunologically before exposure to HIV and have participated in detailed follow up studies

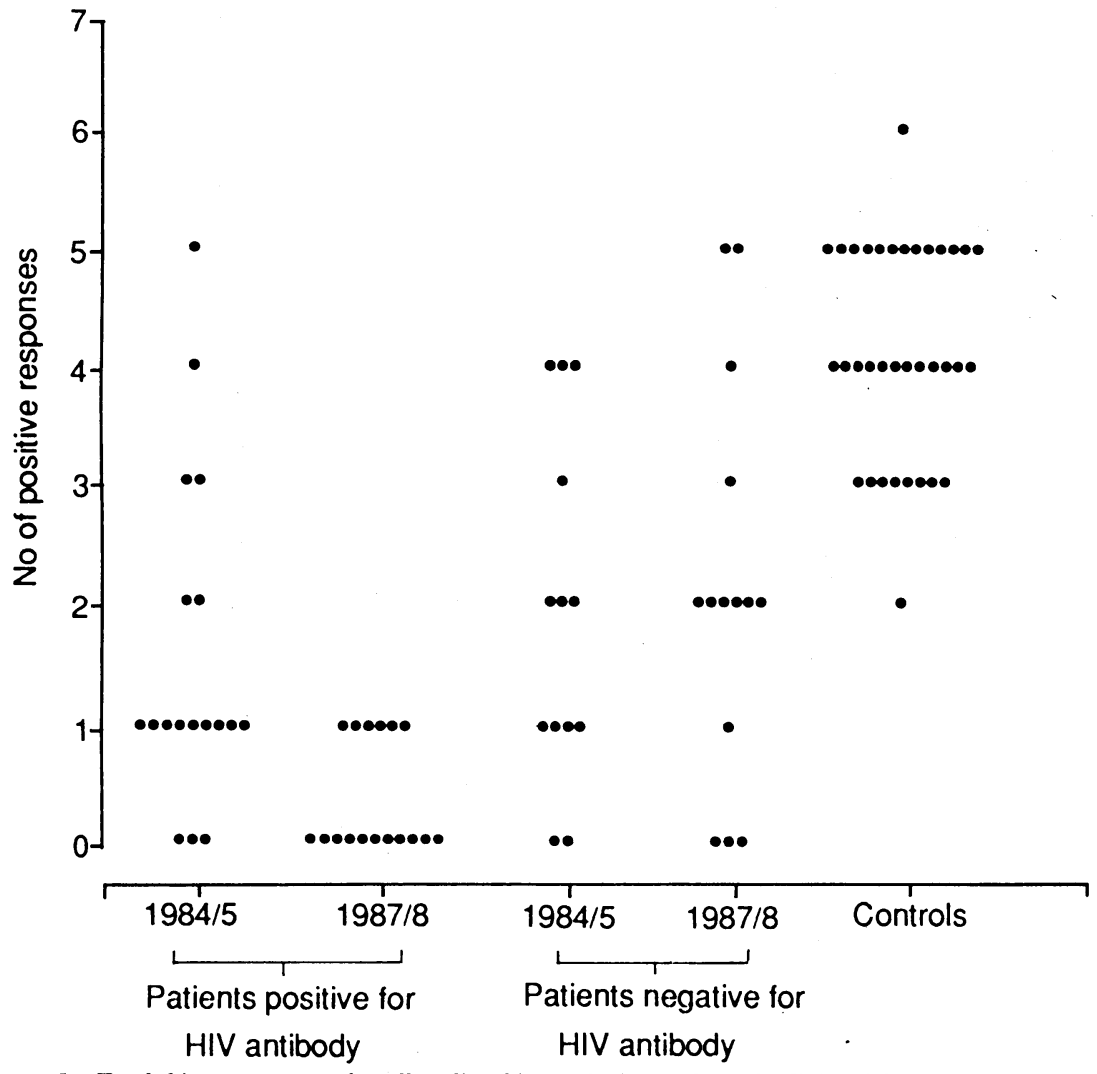

FIG 5-Total skin test responses for cell mediated immunity in members of Edinburgh haemophiliac cohort, 1984-5 and 1987-8. Controls were 35 healthy members of nursing, medical, and laboratory staff at regular intervals. It has thus been possible to record changes in those measures of immune state that have been proposed as markers for HIV related disease and to establish how well or otherwise they correlate with clinical disease progression. This is important not only for understanding of the immunopathogenesis of AIDS but, more specifically, for identifying variables that may be used to assess response when treatment is introduced before symptoms are expressed.

Our previous studies identified the HLA haplotype A1 B8 DR3 as a predictor of rapid progression to symptomatic disease after infection with HIV-I, ${ }^{18}$ and this was later corroborated in the American multicentre AIDS cohort study ${ }^{19}$ and in an Australian report. ${ }^{20} \mathrm{We}$ also showed that the presence of circulating p24 antigen and successful isolation of the virus from cultured blood lymphocytes correlate with the development of HIV related symptoms in this cohort. ${ }^{14}$

None of the six immunological variables included here and none of the clinical characteristics of the patients (age, severity of haemophilia, and extent of liver disease) distinguished the 18 patients who subsequently seroconverted from the 14 who remained negative for HIV antibody. Once infection was established, however, several markers correlated with rate of disease progression. Only CD8 counts and skin tests for cell mediated immunity gave no useful information. The most reliable guide seemed to be serial estimation of numbers of circulating CD4 cells, confirming the findings in virtually all other longitudinal cohort studies. Plasma $\beta_{2}$ microglobulin concentration was of almost equal value in charting the course of disease and seemed to be a better predictor of the impending onset of symptoms. Within the subgroups with and without symptoms high (and rising) plasma IgA concentration correlated well with the presence of clinically evident disease but was of little predictive value whereas plasma neopterin concentration showed striking fluctuations with time, although it too mirrored disease activity and, in a proportion of cases, showed a striking rise in advance of CDC category IV symptoms.

It is important to recognise that individual patients may show patterns of change in these surrogate "markers" that may confound even the clearest associations emerging from group data. One member of the cohort with HIV antibody remained well despite falling CD4 counts $\left(<0.2 \times 10^{9} / 1\right.$ from mid-1988), rising plasma $\beta_{2}$ microglobulin and neopterin concentrations (from late 1984), and, during 1989, a plasma IgA concentration of $5.4 \mathrm{~g} / \mathrm{l}$. At this stage we have monitored the evolution of HIV related disease to CDC category IV in only 10 patients, which is insufficient for valid multiple regression analysis that may eventually provide an index of disease state based on several measures of immune function. The continuing fall in CD4 counts for the subgroup without symptoms and the evidence of rising plasma $\operatorname{IgA}, \beta_{2}$ microglobulin, and neopterin concentrations over the past 18 months in several of these patients suggest that such an analysis may become possible.

Our limited experience with zidovudine in this cohort showed no dramatic or consistent effect on any of the variables studied, but for assessing response to treatment in individual patients before the onset of symptoms ${ }^{21}$ reversal of decline in numbers of CD4 cells and of rising plasma $\beta_{2}$ microglobulin, neopterin, and IgA concentrations may all be taken as evidence of benefit, as indeed may restoration of skin test activity. Confidence in the efficacy of the treatment should be influenced by the overall number of these favourable signs that is recorded in any group of trial patients.

1 Moss AR. Predicting who will progress to AIDS: at least four laboratory parameters available. Br Med f 1988;297:1067-8. 
2 Eyster ME, Gail MH, Ballard JO, et al. Natural history of immunodeficiency virus infections in hemophiliacs: effects of $\mathrm{T}$ cell subsets, platelet counts and age. Ann Intern Med 1987;107:1-11.

3 Lee CA, Phillips A, Elford J, et al. The natural history of human immunodeficiency virus infection in a haemophilic cohort. Br f Haematol 1989;73: 228-34.

4 Polk BF, Fox R, Brookmeyer R, et al. Predictors of the acquired immunodeficiency syndrome developing in a cohort of seropositive homosexual men. N Engl f Med 1987;316:61-6.

5 Moss AR, Bacchetti P, Osmond D, et al. Seropositivity for HIV and the development of AIDS or AIDS related condition: three year follow up of the San Francisco General Hospital cohort. Br Med f 1988;296:745-50.

6 Munoz A, Carey V, Saah AJ, et al. Predictors of decline in CD4 lymphocytes in a cohort of homosexual men infected with human immunodeficiency virus. Fournal of the Acquired Immunodeficiency Syndrome 1988;1:396-404.

7 Pedersen C, Kolby P, Sindrup J, et al. The development of AIDS or AIDSrelated conditions in a cohort of HIV antibody-positive homosexual men during a 3 year follow-up period. Foumal of Internal Medicine 1989;225: 403-9.

8 Lefrere JJ, Lambin P, Courouce AM, Doinel C. Progression to AIDS in the majority of asymptomatic HIV-infected people. AIDS 1989;3:603-4.

9 Fuchs D, Hansen A, Reibnegger G, et al. Neopterin as a marker for activated cell-mediated immunity: application in HIV infection. Immunology Today cell-mediated

10 Sears SD, Fox R, Brookmeyer R, et al. Delayed hypersensitivity skin testing and anergy in a population of gay men. Immunopathology 1987;45:177-83.

1 Brettler DB, Forsberg AD, Brewster AD. Delayed cutaneous hypersensitivity reactions in hemophiliac subjects treated with factor concentrate. $\mathrm{Am} \mathcal{F} \mathrm{Med}$ 1986;81:607-11
12 Ludlam CA, Tucker J, Steel CM, et al. Human T lymphotropic virus type III HTLV-III) infection in seronegative haemophiliacs after transfusion with factor VIII. Lancet 1985; ;i:233-6.

13 Simmonds P, Lainson FAC, Cuthbert RJG, et al. HIV antigen and antibody detection: variable responses to infection in the Edinburgh haemophiliac cohort. Br Med F 1988;296:593-8.

14 Cuthbert RJG, Ludlam CA, Rebus $S$, et al. Human immunodeficiency virus detection: correlation with clinical progression in the Edinburgh haemophiliac cohort. Brf Haematol 1989;72:387-90.

15 Mildvan D, Solomon SL. The spectrum of disease due to human immunodeficiency virus. Current Topics in AIDS 1987;1:31-55.

16 Carr R, Edmund E, Prescott RJ, et al. Abnormalities of circulating T cell subsets in haemophiliacs in an AIDS-free population. Lancet 1984; $1431-74$

17 Jin Z, Cleveland RP, Kaufman DB. Immunodeficiency in patients with hemophilia: an underlying deficiency and lack of correlation with factor replacement therapy or exposure to human immunodeficiency virus. f Allergy Clin Immunol 1989;83:165-70.

18 Steel CM, Beatson D, Cuthbert RJG, et al. HLA haplotype A1 B8 DR3 as a risk factor for HIV-related disease. Lancet 1988;i:1185-8.

19 Kaslow RA, Duquesnoy R, Van Raden M, et al. Al, Cw7, B8, DR3 HLA antigen combination associated with rapid decline of $\mathrm{T}$-helper lymphocytes in HIV-1 infection. Lancet 1990;335:927-30.

20 Mallal S, Cameron PU, French MAH, Dawkins RL. MHC genes and HIV infection. Lancet 1990;335:1591-2.

21 Anonymous. Clinical trials of zidovidine in HIV infection [Editorial]. Lancet 1989;ii:483-4.

(Accepted 25 fuly 1990)

\title{
Effects of discrimination by sex and race on the early careers of British medical graduates during 1981-7
}

\author{
P M McKeigue, J D M Richards, P Richards
}

Abstract

Objective-To examine the possible effects of discrimination by sex and race on the career patterns of doctors up to six years after qualifying.

Design-Postal questionnaire follow up survey.

Participants - 1572 Doctors who graduated from five British medical schools in 1981, 1983, and 1985, including 587 women and 131 doctors from ethnic minorities.

Main outcome measures-Reported success rates of applications for training posts.

Results-Comparison of the career patterns of women and men yielded no evidence of discrimination against women in competition for posts. In contrast, there were striking differences in career patterns between graduates of native European origin and those of ethnic minority origin. Graduates from ethnic minorities reported lower success rates and more difficulty in obtaining house officer posts, registrar posts, and places in vocational training schemes in general practice. Most of this discrimination seemed to occur at the stage of shortlisting for interview. Graduates from ethnic minorities were more likely than graduates of native European origin to have experienced spells of unemployment while seeking work. They were also more likely to have changed their original choice of career because of difficulty in obtaining suitable training posts or unfavourable career prospects.

Conclusions-Discrimination against ethnic minorities occurs in the competition for training posts among graduates from British medical schools. There was no evidence of discrimination against women graduates. Shortlisting procedures based on objective scoring systems may help to ensure equality of opportunity in future.

Dr P M McKeigue

Department of

Epidemiology and

Population Studies, London

School of Hygiene and

Tropical Medicine, London WCIE 7HT.

BrMed f 1990;301:961-4 medical school, ${ }^{3}$ and analysis of the proportions of students at other medical schools who had nonEuropean names suggests that this was not an isolated instance. ${ }^{1}$ The only available data on the career patterns of British trained doctors from ethnic minorities are from a survey of hospital doctors in two northern regions in $1980 .{ }^{4}$ The results suggested that doctors from ethnic minorities, whether trained in Britain or overseas, were experiencing disproportionate difficulty in obtaining hospital posts compared with their native European counterparts. The survey, however, was not based on a representative sample of medical graduates, and the number of British trained doctors from ethnic minorities was very small. In 1987 the University Hospitals Association decided to undertake a survey of the careers of recent medical graduates to examine the problems experienced by this group in obtaining suitable training posts and pursuing their chosen careers. ${ }^{5}$ We examined this dataset for evidence of discrimination by sex and race.

\section{Methods}

Five medical schools were chosen to make up a geographically representative sample. Questionnaires were sent during 1987 to all 2002 medical graduates who qualified during 1981,1983 , and 1985 at these five medical schools accompanied by a covering letter from the dean of each graduate's medical school. To maintain confidentiality questionnaires were identified only by serial number. Linkage to names and addresses was used only to identify non-respondents, who were sent a reminder letter. A total of 1572 replies were received, giving a response rate of $79 \%$.

The questionnaire included items on demographic background, career choice, and intended postgraduate qualifications at the time of completing the preregistration year; numbers of unsuccessful applications submitted before obtaining each senior house officer and registrar post; numbers of interviews for each post without the offer of a job; and present career choice. Those who had changed their first choice of career since completing the preregistration year were asked to 